\title{
Przepis na ludoteki. Finansowanie wypożyczalni gier ze środków budżetu partycypacyjnego w Polsce
}

Recipe for game lending libraries. Participatory budget as a way of financing the creation of game lending libraries in Poland

\author{
Marcin Łączyński \\ Uniwersytet Warszawski \\ laczynski.marcin@gmail.com | ORCID: 0000-0002-9266-225x
}

\begin{abstract}
This article aims to discuss legal and organizational aspects of funding toy and game lending libraries with money from participatory budgets in Poland. It presents a case study of development and promotion of such project, based on a project "Wypożyczalnie gier planszowych w bibliotece" conducted in 2016 in six areas of Warsaw. The article presents organizational and procedural aspects of the project development, execution and promotion within the participatory budget procedure and outside, as well as public opinion, reactions of city officials and of people responsible for the realization of the project after it was voted through, and its results.
\end{abstract}

Keywords: participatory budgeting, boardgames, civic engagement, toy lending libraries, game lending libraries 



\section{Wprowadzenie}

Bezpośrednią inspiracją do przygotowania tego artykułu była publikacja autorstwa Magdaleny Litwin Gry i zabawy w instytucjach kultury. O (nie) możliwości utworzenia ludotek $w$ Polsce (Litwin, 2015), poświęcona funkcjonowaniu - w różnych krajach - instytucji ludotek, czyli wyspecjalizowanych wypożyczalni gier i zabawek, a także rozpatrywaniu szans na uruchomienie takich wypożyczalni w Polsce. Na świecie instytucje tego typu działają od ponad 8o lat, a za pierwszą z nich uznawana jest wypożyczalnia powołana w roku 1935 w Los Angeles (Moore, 1995). Opisując specyfikę funkcjonowania ludotek, Litwin stawia w podsumowaniu swojego tekstu tezę, że w polskich realiach najlepszy (i potencjalnie jedyny) realny sposób instytucjonalnego poszerzania dostępu do gier i zabawek stanowi udostępnianie ich w istniejącej sieci wypożyczalni książek jako kolejnej kategorii zbiorów. W dalszej części tekstu zaprezentowany zostanie opis projektu „Wypożyczalnie gier planszowych w bibliotece” i wnioski z realizacji jego dwóch edycji w latach 2016 i 2017 w ramach warszawskiego budżetu partycypacyjnego (dalej: BP). Projekt ten jest praktyczną egzemplifikacja tezy sformułowanej przez Litwin i pokazuje, jak duży potencjał popularyzacji nowoczesnych gier planszowych tkwi w rozwoju i upowszechnianiu budżetów partycypacyjnych w polskich miejscowościach.

\section{Gry planszowe w budżetach partycypacyjnych}

$\mathrm{W}$ artykule tym stosujemy szeroką definicję BP, podaną na stronie MaszGlos.pl przez Fundację im. Stefana Batorego:

Budżet obywatelski, nazywany również partycypacyjnym, to proces, w którym mieszkańcy decydują o przeznaczeniu części lub całości budżetu danego miasta lub gminy. Decyzje mogą być podejmowane bezpośrednio przez mieszkańców bądź za pośrednictwem organizacji społecznych. Najważniejszym elementem budżetu obywatelskiego są regularne spotkania mieszkańców z przedstawicielami władz, podczas których rozmawia się o przeznaczeniu wspólnych pieniędzy (Kraszewski, b.d.).

BP (w polskich realiach wymiennie używane jest także określenie „budżety obywatelskie") są w naszym kraju stosunkowo nowym zjawiskiem w zakresie zaangażowania mieszkańców w proces decyzyjny dotyczący 
kierunków realizacji polityk publicznych i inwestycji. Pierwsza taka forma włączenia członków danej społeczności w proces decyzyjny została w Polsce wdrożona w 2011 roku w Sopocie (Kłębowski, 2013), a już w 2013 roku w raporcie Fundacji Batorego odnotowano wydzielenie środków, o których przeznaczeniu decydują w głosowaniu mieszkańcy, w budżetach 62 miast w całej Polsce (Kraszewski, Mojkowski, 2014). Jednocześnie autorzy badań i analiz ewaluacyjnych dotyczących funkcjonowania budżetów partycypacyjnych wskazują na występowanie szeregu słabości tej formy finansowania inicjatyw oddolnych i dużą dynamikę zmian, wynikającą $\mathrm{z}$ trwającego nieustannie procesu wypracowywania standardów i ram organizacyjnych dla budżetów obywatelskich (Kłębowski, 2014).

Pełne omówienie treści wszystkich tych budżetów w Polsce przekracza ramy niniejszego artykułu, ale w celu pokazania skali zainteresowania kwestią popularyzacji gier jako tematem poruszanym w projektach składanych do budżetu obywatelskiego szczegółowo przeanalizowano na potrzeby tego tekstu - archiwa projektów z każdego z miast wojewódzkich od początku realizacji BP w każdym z tych ośrodków. Analiza owa pokazała daleko idącą asymetrię w liczbie działań zorientowanych na popularyzację gier planszowych w ramach budżetu obywatelskiego. Zidentyfikowano następujące projekty:

- Katowice - jeden projekt utworzenia wypożyczalni gier w Miejskim Domu Kultury, odrzucony w głosowaniu przez mieszkańców;

- Kraków - jeden projekt utworzenia wypożyczalni gier w Miejskim Domu Kultury, sfinansowany i zrealizowany;

- Warszawa - 27 projektów utworzenia wypożyczalni gier w bibliotekach, mediatekach, centrach aktywności lokalnej lub domach kultury; wszystkie uzyskały finansowanie decyzją mieszkańców, wyrażoną w głosowaniu.

Analizując mechanizmy działania BP i specyfikę stosowania tej formy finansowania w Polsce, należy wskazać na dwa istotne czynniki wpływające na możliwość tworzenia projektów podobnych do opisanego w dalszej części artykułu, poza samym zainteresowaniem mieszkańców grami.

Pierwszym z tych czynników jest dopuszczenie - na poziomie regulaminu wyznaczającego ramy proceduralne BP lub na poziomie niepisanej praktyki organizacyjnej - projektów „miękkich”, tj. niezorientowanych na finansowanie trwałej infrastruktury, takiej jak ścieżki rowerowe, siłownie 
plenerowe, przejścia dla pieszych, nawierzchnia ulicitd. Jak pokazują wyniki ewaluacji funkcjonowania BP prezentowane przez Instytut Obywatelski, w 2014 roku aż 24,7\% miast nie dopuszczało w ogóle realizacji projektów innych niż trwałe inwestycje (Kłębowski, 2014, s. 26). W analizie dokonanej na potrzeby tego artykułu stwierdzono, że spośród miast wojewódzkich w Szczecinie, Gorzowie Wielkopolskim i Zielonej Górze do procedowania w ogóle nie były dopuszczane projekty inne niż inwestycje infrastrukturalne.

Drugim czynnikiem ograniczającym możliwość realizacji projektów wypożyczalni gier w ramach istniejących instytucji kultury jest zaistnienie i utrwalenie $w$ danym mieście praktyki wskazywania tych instytucji jako podmiotów odpowiedzialnych za realizację projektów finansowanych z BP. Możliwość lokalizacji wypożyczalni gier w wybranej instytucji kultury zależy od:

- woli zarządu tej instytucji - wszystkie badane regulaminy BP w miastach wojewódzkich uzależniają realizację projektu w wybranej instytucji od uzyskania zgody jej kierownictwa;

- praktyki urzędników kwalifikujących projekt do konsultacji i głosowania - w wielu przypadkach badanie faktycznych kryteriów kwalifikacji projektów zgłoszonych przez mieszkańców wskazuje w dalszym ciągu na arbitralność decyzji o odrzuceniu danej propozycji, często z nie do końca jasnych lub pozaregulaminowych powodów, z których jednym może być m.in. niedopuszczanie w ogóle danego typu lokalizacji (bibliotek, domów kultury itd.) dla projektu (Kłębowski, 2014, s. 17-18).

W dalszej części artykułu zaprezentowany zostanie opis przygotowania koncepcji i realizacji projektu, który posłużył do przeprowadzenia z sukcesem 9 z 27 przyjętych wniosków o stworzenie - ze środków warszawskiego BP - wypożyczalni gier planszowych w ramach istniejących instytucji kultury.

\section{Koncepcja projektu „Wypożyczalnie gier planszowych w bibliotece"}

Projekt „Wypożyczalnie gier planszowych w bibliotece” został wymyślony pod koniec 2015 roku przez autora niniejszego artykułu oraz Katarzynę 
Kotarską z Fundacji „Pragmatica”. W projekcie tym autorzy zakładali umożliwienie - w ramach istniejących wypożyczalni dzielnicowych w Warszawie - udostępniania odwiedzającym nowoczesnych gier planszowych, w tym zagrania na miejscu lub wypożyczenia ich do domu. W pierwszej edycji projektu został on złożony w następujących obszarach warszawskiego вр:

- Wola Młynów,

- Mokotów, rejon B,

- Mokotów, rejon C,

- Mokotów, rejon F,

- Śródmieście, obszar Sawa,

- Śródmieście, obszar Wars.

Opis projektu skierowany do urzędników oceniających zasadność jego złożenia i do mieszkańców na etapie głosowania prezentował założenia w następujący sposób:

Wypożyczanie gier planszowych to nowy pomysł na wzbogacenie oferty kulturalnej, rekreacyjnej i edukacyjnej dostępnej dla mieszkańców Warszawy. Od kilku lat gry planszowe stają się coraz powszechniejszą formą rodzinnej rozrywki i alternatywą dla spędzania czasu przy komputerze i telewizji. Wypożyczalnia możne być sposobem na poznanie nowych, ciekawych, rozwijających gier (Kotlarska, 2017).

W uzasadnieniu projektu zawarta została także informacja o tym, dlaczego wybrano akurat gry jako istotny rodzaj zasobów poszerzających ofertę bibliotek:

Gry planszowe mają bogate walory edukacyjne, wpływają na kształtowanie się, szczególnie u dzieci i młodzieży, wielu kompetencji intelektualnych, a przede wszystkim są atrakcyjną formą spędzania czasu, pogłębiającą relacje międzyludzkie.

Aktualna oferta gier planszowych na rynku jest bardzo różnorodna, lecz jej dostępność jest ograniczona $\mathrm{z}$ racji dość wysokiej ceny zakupu. Wypożyczalnia gier umożliwia dostęp wszystkim zainteresowanym [w]arszawiakom do ciekawych, nowych gier.

Poza opisem i uzasadnieniem projekt zawierał także szczegółowy kosztorys, uwzgledniający w pierwszej edycji koszty zakupu gier, szafek do przechowywania zbiorów oraz materiałów promocyjnych z informacjami o poszerzeniu oferty danej biblioteki o gry planszowe - przy czym główną część budżetu (ponad 90\%) stanowiły wydatki na zakup gier. 
W szczegółowej deskrypcji projektu znalazły się także informacje o kryteriach kwalifikacji gier do zakupów. Ujęte tam zostały następujące kategorie gier, wraz ze wskazaniem potencjalnych walorów edukacyjnych tytułów z każdej kategorii:

- quizy i gry rozwijające wiedzę encyklopedyczną,

- gry strategiczne, rozwijające umiejętności planowania i przewidywania,

- gry kooperacyjne, rozwijające umiejętności komunikacji i współpracy,

- gry logiczne, rozwijające myślenie analityczne,

- rozrywkowe gry rodzinne, nadające się do wspólnej zabawy dla dzieci i dorosłych.

W zależności od dzielnicy szczegółowa alokacja środków na poszczególne kategorie była różna, ale zachowana została szacunkowa proporcja przeznaczenia finansowania $\mathrm{z}$ budżetu, wynikająca $\mathrm{z}$ chęci zapewnienia zróżnicowanej oferty w sytuacji, kiedy cena za egzemplarz gry waha się od ok. 30 zł (gry rodzinne i quizy) do ponad 150 zł (duże gry strategiczne):

- quizy i gry rozwijające wiedzę encyklopedyczną - do 10\% budżetu,

- gry strategiczne - ponad $20 \%$,

- gry kooperacyjne - ok. $15 \%$,

- gry logiczne - ok. 20\%,

- gry dla młodszych dzieci - do $10 \%$,

- rozrywkowe gry rodzinne - ok. $20 \%$.

Tak rozłożony budżet pozwalał zakupić od 50 do 60 egzemplarzy różnych gier planszowych. Dodatkowo w projekcie zawarte zostało ograniczenie dotyczące zakupu - ze środków budżetowych - wyłącznie gier wydanych po 1990 roku, co miało być przez realizatorów projektu weryfikowane za pomocą bazy danych serwisu BoardGameGeek.com.

Całkowity budżet projektu wynosił, w zależności od dzielnicy, między 3400 a 4000 zł i celowo był utrzymany na tak niskim poziomie $\mathrm{z}$ powodu konstrukcji regulaminu BP $\mathrm{w}$ Warszawie. Zgodnie z zapisem $\S 35$ pkt. 4 owego regulaminu:

W sytuacji, gdy pozostałe środki finansowe nie pozwalają na realizację kolejnego projektu z listy rankingowej, za rekomendowany do realizacji uznaje się projekt zajmujący niższą pozycję na liście, jeżeli koszty jego realizacji mieszczą się w kwocie pozostałej do rozdysponowania. 
Na podstawie danych z poprzednich edycji BP jako średnią wartość puli niewykorzystanych środków na każdym obszarze wyliczono kwotę 3800 zł. Oznaczało to, zgodnie z § 35 pkt. 4 regulaminu, że projektowi o takiej lub niższej wartości wystarczy z dużym prawdopodobieństwem tylko jeden głos do tego, aby został wybrany do realizacji. Była to ze strony autorów projektu celowa strategia, maksymalizująca szansę na sukces w głosowaniu. Później okazało się to jednak niekonieczne, ponieważ projekt uzyskał bardzo dużą liczbę głosów.

\section{Realizacja projektu „Wypożyczalnie gier planszowych w bibliotece"}

Proces realizacji projektu obejmował następujące etapy poprzedzające powstanie wypożyczalni gier w warszawskich bibliotekach:

- zbieranie podpisów na listach poparcia (wymóg minimum 30, $\mathrm{z}$ numerem PESEL);

- złożenie wniosku do urzędu dzielnicy;

- uwzględnienie uwag od urzędników;

- publiczne prezentacje wniosku na spotkaniach z mieszkańcami;

- publikacja wniosku - po konsultacjach - na stronie BP;

- uruchomienie głosowania i promocja projektu wśród głosujących;

- wybór projektu;

- kontakt z instytucją realizującą projekt i rekomendacje tytułów gier;

- zakup gier i promocja ich wypożyczania przez bibliotekę.

Podpisy do projektu zbierano wśród zaprzyjaźnionych osób grających w gry planszowe oraz podczas wydarzeń publicznych w styczniu 2016 na terenie Warszawy (m.in. finał Wielkiej Orkiestry Świątecznej Pomocy). Istotne ograniczenie stanowiła konieczność pozyskania numeru PESEL, co wymagało maksymalnego uwiarygodnienia osób zbierających podpisy - podpisującym prezentowano informacje o zbierającym i o projekcie, podawano także adres jego strony internetowej itd.

Po złożeniu wniosków oraz list z podpisami treść projektu i list poparcia zweryfikowali urzędnicy. Jedyna uwaga, jaka pojawiła się na etapie korekty formalnej i merytorycznej, dotyczyła zmiany alokacji środków na meble i miejsce do przechowywania gier. Jak się okazało, wybrane 
biblioteki umożliwiły umieszczenie zasobów gier w już istniejących regałach i szafkach, co pozwoliło na przekierowanie kwoty z planowanego nabycia mebli na zakup większej liczby gier.

Po etapie formalnej weryfikacji projektów następowała ich prezentacja na spotkaniach z mieszkańcami. Autorzy omawianej propozycji musieli się stawić osobiście na jednym spotkaniu w każdym z obszarów budżetu i przedstawić założenia w ciągu dwóch minut. Przyjęcie pomysłu na tych spotkaniach było powszechnie pozytywne, a zgłaszane przez mieszkańców uwagi obejmowały:

- zwiększenie wartości projektu (w kilku obszarach została ona podniesiona z 3400 do 3800-4000 zł);

- możliwość wprowadzenia systemu przekazywania używanych gier do wypożyczalni przez osoby, które już w nie grają (biblioteki rozważają takie rozwiązanie, ale aktualnie nie zostało ono nigdzie wprowadzone).

Po zakończeniu etapu konsultacji projekty publikowano w finalnej postaci na stronie BP, po czym od 14 do 24 czerwca 2016 odbywało się głosowanie internetowe i tradycyjne. Równolegle prowadzono działania promocyjne, które obejmowały:

- publikację informacji na blogu Gry-Szkoleniowe.blogspot.com i jego fanpagéu w serwisie Facebook;

- publikację informacji o projekcie na grupach i fanpage'ach o tematyce planszówkowej w serwisie Facebook;

- publikację informacji o projekcie na grupach lokalnych w serwisie Facebook;

- posty sponsorowane w serwisie Facebook;

- wysyłkę informacji mailowych do osób, które podpisywały listy poparcia projektu;

- umieszczanie ulotek promujących projekt w kawiarniach, w których można grać w gry planszowe;

Dodatkowo informację o projekcie otrzymało bezpośrednio blisko 100 osób, które wzięły udział w spotkaniach na etapie konsultacji treści propozycji.

Wyniki głosowania pokazały, że w Warszawie istnieje bardzo duże zapotrzebowanie na wypożyczalnie gier planszowych w miejskich bibliotekach. Uzyskane liczby głosów kształtowały się następująco: 
- Śródmieście Sawa - 997 głosów (I miejsce);

- Wola Młynów - 454 głosy (Ir miejsce);

- Mokotów Rejon C - 769 głosów (III miejsce);

- Mokotów Rejon F - 565 głosów (III miejsce);

- Mokotów Rejon B - 961 głosów (brak danych);

- Śródmieście Wars - 617 głosów (brak danych);

- $\mathrm{w}$ sumie -4363 głosy.

\section{Ocena działań w projekcie "Wypożyczalnie gier planszowych w bibliotece"}

Po pierwszej edycji projektu i zakończeniu głosowania, podczas podsumowania, zespół autorów następująco ocenił przeprowadzone działania:

Mocne strony:

- opis projektu - zaprezentowany w sekcji trzeciej tego artykułu, okazał się wystarczający do wzbudzenia poparcia u osób interesujących się BP, a ewentualne wątpliwości i głosy krytyczne, których spodziewali się autorzy, nie zostały zwerbalizowane podczas spotkań z mieszkańcami ani w komentarzach w internecie;

- zaangażowanie osób podpisujących listy poparcia - okazało się, że nawet obce autorom osoby, z którymi utrzymywano komunikację dotyczącą przebiegu projektu (drogą mailową), należały do jego orędowników i z ochotą informowały o nim swoich znajomych;

- zaangażowanie bibliotekarzy - z uniwersalnie pozytywną reakcją zespół projektowy spotkał się także ze strony bibliotekarzy i kierowników bibliotek, którzy chętnie konsultowali tytuły do zakupu, organizowali miejsce do przechowywania gier oraz wypracowali zasady wypożyczania dla nietypowych zbiorów, jakimi są gry planszowe;

- komunikacja na blogu - uzyskano wysokie wskaźniki kontaktu z treściami dotyczącymi projektu w mediach społecznościowych (blisko 500 wyświetleń wpisów na temat projektu na blogu Gry-Szkoleniowe.blogspot.com, a w serwisie Facebook zasięg organiczny [bezpłatny] wyniósł 6730 odsłon przy 1800 osób lubiących stronę).

- powodzenie pomysłu w pierwszym roku spowodowało szerokie jego naśladownictwo w propozycjach innych autorów (widoczne 
w niemal identycznej konstrukcji projektu, argumentacji za jego realizacją i propozycji budżetu) w kolejnych edycjach вр oraz doposażenie szeregu dalszych punktów bibliotecznych i innych instytucji kultury w gry zakupione z myślą o wypożyczaniu.

Słabe strony:

- niedoszacowanie skali poparcia dla projektu, przez co budżet był niższy niż możliwy do przegłosowania. W kolejnej edycji вP, na 2018 rok, odbywającej się w 2017 roku, budżety na każdy obszar podniesiono do ponad 7000 zł (ponownie projekt został przegłosowany w 3 z 3 obszarów, w których go złożono);

- dodatkowa promocja - przeprowadzono trzy czterodniowe kampanie, które uzyskały każdorazowo wysoki opłacony zasięg: średnio ok. 12300 wyświetleń płatnych przy budżecie 40 zł na kampanię; zarazem jednak kampanię płatną cechował niski (poniżej 0,5\%) CTR (click through rate - wskaźnik tego, jaki procent osób wyświetlających kliknął w reklamę [Kozielski, 2011, s.494]). Może z tego wynikać, że odbiorcy nie są przyzwyczajeni do celowej promocji projektów w BP za pomocą reklamy i nie najlepiej reagują na tego typu formę informacji;

- udział w części spotkań promocyjnych - problematyczna dla autorów była konieczność stawienia się na niektórych spotkaniach informacyjnych, jeśli udział brało w nich tylko kilka osób spośród mieszkańców.

\section{Podsumowanie}

Autorzy projektu sprawdzili za pomocą wyszukiwarki tytułów popularność zakupionych gier w bibliotekach dla Warszawy Mokotowa (trzy placówki w tej dzielnicy posiadają takie gry) 3, 12 i 18 grudnia 2018. Analiza ta wykazała, że średnio w badanym czasie wypożyczone było ok. 23\% dostępnych gier, a więc w zależności od biblioteki - od 12 do 15 tytułów. Nawet przyjmując niższą liczbę i okres wypożyczenia jednej gry na maksymalnie 14 dni, uzyskujemy ponad 300 wypożyczeń gier dla jednej biblioteki w skali roku (mówimy tu o szacunkowym wykorzystaniu gier zakupionych z BP, ponieważ realne zbiory są obecnie większe i sama 
biblioteka dalej rozwija zasób gier planszowych w wypożyczalni). Skala zainteresowania grami dwa lata po realizacji projektu pokazuje, że istnieje grupa użytkowników bibliotek publicznych, dla których zasoby te stanowią atrakcyjną pozycję w katalogu i są chętnie wykorzystywane jako forma rozrywki lub edukacji. Część tytułów wypożyczanych stanowią bowiem te o wyraźnie edukacyjnym charakterze, takie jak np. Wojenna odyseja Antka Srebrnego 1939-1945 autorstwa Tomasza Łabuszewskiego czy Ale Historia autorstwa Filipa Miłuńskiego. Przy uwzględnieniu ograniczeń opisanych w drugiej części tego tekstu można zauważyć, że na podstawie omówionego projektu i zainicjowanego przezeń procesu doposażania warszawskich bibliotek w gry planszowe budżet partycypacyjny (obywatelski) wydaje się właściwym narzędziem pozwalającym inicjować powstawanie takich zbiorów bibliotecznych i popularyzować korzystanie z nowoczesnych gier planszowych.

\section{Literatura}

Bluj, A., Stokłuska, E. (2015). Budżet partycypacyjny (obywatelski) krok po kroku. Poradnik dla praktyków. Warszawa: Fundacja Pracownia Badań i Innowacji Społecznych „Stocznia”. Online: <http://partycypacjaobywatelska.pl/wp-content/uploads/2016/o1/BP_krokpokroku.pdf >. Data dostępu: 15 października 2020.

Kłębowski, W. (2013). Budżet partycypacyjny. Krótka instrukcja obsługi. Warszawa: Instytut Obywatelski. Online: <http://www.instytutobywatelski.pl/wp-content/uploads/2013/o3/budzet_partycypacyjny.pdf>. Data dostępu: 15 października 2020.

Kłębowski, W. (2014). Budżet partycypacyjny. Ewaluacja. Warszawa: Instytut Obywatelski. Online: <http://www.instytutobywatelski.pl/21598/ publikacje/raporty/raport-budzet-partycypacyjny-ewaluacja>. Data dostępu: 15 października 2020.

Kotlarska, K. (2017). Wypożyczalnie gier planszowych w bibliotece - Wola, obszar 4: Młynów. Online: <http://app.twojbudzet.um.warszawa.pl/ projekt/4313>. Data dostępu: 12 grudnia 2018.

Kozielski, R. (2011). Wskaźniki marketingowe. Warszawa: Wolters Kluwer Polska. 
Kraszewski, D. (b.d.). Budżet obywatelski. Online: <http://www.maszglos. $\mathrm{pl} / \mathrm{strefa-wiedzy/budzet-obywatelski/budzet-obywatelski-krok-i>.}$ Data dostępu: 10 grudnia 2018.

Kraszewski, D., Mojkowski, K. (2014). Budżet obywatelski w Polsce. Warszawa: Fundacja im. Stefana Batorego. Online: <http://partycypacjaobywatelska.pl/wp-content/uploads/2015/o7/Budzet-obywatelski-w-Polsce-D.-Kraszewski-K.-Mojkowski.pdf>. Data dostępu: 15 października 2020.

Litwin, M. (2015). Gry i zabawy w instytucjach kultury. O (nie)możliwości utworzenia ludotek w Polsce. Homo Ludens. 7(1), 145-158. Online: <http://www.ptbg.org.pl/?smd_process_download=1\&download_ id=2582 >. Data dostępu: 15 października 2020.

Moore, J. E. (1995). A History of Toy Lending Libraries in the United States Since 1935. Online: <http://eric.ed.gov/?id=ED390414>. Data dostępu: 10 grudnia 2018.

Pietrusińska, M. J. (2017). Budżet partycypacyjny jako potencjał edukacji obywatelskiej dorosłych. Przykład Warszawy. Pedagogika Społeczna, 65(3), 157-175.

Regulamin budżetu partycypacyjnego w Warszawie. Online: <http:// twojbudzet.um.warszawa.pl/sites/twojbudzet.um.warszawa.pl/files/ regulamin_przeprowadzania_budzetu_partycypacyjnego_w_warszawie_na_rok_2019.pdf>. Data dostępu: 10 grudnia 2018.

Rettig, M. A. (1998). Guidelines for Beginning and Maintaining a Toy Lending Library. Early Childhood Education Journal, 25(4), 229-232.

mgr Marcin Łączyński - medioznawca, socjolog, projektant gier. Członek zespołu Fundacji „Pragmatica”, współpracownik Laboratorium Badań Medioznawczych uw

\title{
Przepis na ludoteki. Finansowanie wypożyczalni gier ze środków budżetu partycypacyjnego
}

\begin{abstract}
Abstrakt: Celem artykułu jest omówienie prawnych i organizacyjnych aspektów finansowania wypożyczalni gier ze środków dostępnych w miejskich budżetach partycypacyjnych. Zaprezentowana została w nim szczegółowa analiza przypadku tworzenia i promowania takiego wniosku o finansowanie, dokonana na przykładzie projektu „Wypożyczalnie gier planszowych w bibliotece", z sukcesem przeprowadzonego wiosną
\end{abstract}


2016 w sześciu obszarach Warszawy. W artykule przedstawiono aspekty organizacyjne i proceduralne przygotowania projektu, działania promocyjne - realizowane w ramach przewidzianych przez procedurę budżetu partycypacyjnego, jak i poza nią, informacje zwrotne na temat projektu pozyskane od mieszkańców, reakcje urzędników i osób odpowiedzialnych za realizację projektu po jego przegłosowaniu oraz wyniki przedsięwzięcia.

Stowa kluczowe: budżet obywatelski, gry planszowe, partycypacja społeczna, wypożyczalnie gier 